\title{
On the Customer Behavior of the Customers towards Maruti Suzuki
}

\author{
Kireethi Reddy, Jeyapriya ,Indhumathi
}

\begin{abstract}
CUSTOMER Behavior is must to comprehend the preferences of the client in regards to MARUTI item and administrations.
\end{abstract}

- To evaluate how the channels are understood and how they work. - To understand if the customer gets the item and the administration on timetable. - This would prepare for better channeling and improve the scope of CRM exercises

The scope of the examination is: the study includes the behavior of the customer. - Finding different variables that make the customer dissatisfied and defeat those by better technique. • Channel the dispersion that will allow the client to interact and arrive.

- This study extends its focus on considering separate financial, social, topographical and political elements of the India-Inlet countries exchange.

Keywords : Maruthi Suzuki,Customers.

\section{INTRODUCTION}

Having considered the adjustments in varying backgrounds the HR arrangement is a noteworthy device to mend the HR to rethink their probability. Because of scaling back the remaining burdens are powers on the couple of representatives. Accordingly it is significant for the association to keep every one of its workers in a total fulfillment level to improve their assurance which will bring about the high efficiency of the association. [1-10]

In light of this situation, the present examination features the requirement for preparing, appropriate treatment of complaints arrangement of clean workplace and so on; the critical discoveries will add to detail and faultless system which will cross over any barrier between what they are and what they should be. [11-15]

In Chennai the study was led to discover the fulfillment level of the fulfillment level of the representatives in the association and HR approaches contributing towards increment of fulfillment level of the workers and about its viability achievement esteem expansion changes brought sent and so forth; this criteria have been assessed basically to discover [15-251potential proposals so that in future fulfillment level program will be taken genuine by the association. Graphical representation of customer behavior

Revised Manuscript Received on July 22, 2019.

Kireethi Reddy Department of Management studies,Bharath Institute of Higher Education and Research,Chennai,India.

Jeyapriya Department of Computer science and engineering,,Bharath Institute of Higher Education and Research,Chennai,India

Indhumathi., Department of Management studies,BharathInstitute of Higher Education and Research,Chennai,India.
Ecological powers

Culture, sub-culture, social class, pay, instruction,

Reference gathering, situational factors, family, social worth,

Standards, Roles of showcasing blend factors.

\section{1}

\section{INDIVIDUAL FACTORS}

Thought processes discernment erudition

Frame of mind character

\section{Buy DECISION}

|

Issue data assessment buy post-buy

Recog. Search and altern. Choice conduct

As indicated by Ugala (2001), there are two types of client behaviour, I. E Buyer behavior arranged intellectual and experience. Customers with subjective behavior are legitimate and balanced customers, while experienced customers are increasingly motivated to purchase an item. Dalqvist and Linde(2002) defined customer conducts, for instance, in four phases of sensible, trained, oblivious and social behaviour.

(Information - Attitude - Action).

\section{A. Level Headed Behavior}

Initially, customers with level-headed Behavior gets some product information and what it can offer. They lastly obtain a sense of mind towards the item by evaluating this data ; regardless of whether to purchase the item. For instance, when clients purchase costly products, this kind of conduct is most essential.Vehicles[26]

(Learning - ATTITUDE - ACTION) 


\section{B.Proclamation of problem}

Customer behavior and satisfaction are regarded as the most significant factor because it includes customer retention and makes the brand unwavering. Common customer-based elements Behavior is ; customer nature, compassion, community, life ... and so on. This examination seeks to determine the behavior of the client in relation to SUZUKI products and administrations.[27]

\section{II.ESSENTIAL OBJECTIVE}

-To discover the client conduct of Maruti Suzuki in Bihar.

\section{C.Objective auxiliary}

- To comprehend the significance of four I wheelers. E MARUTI SUZUKI in everyday life. • To examine the factor affecting MARUTI SUZUKI's use and purchase. • Discerning administration.

\section{III.RESTRICTIONS OF THE STUDY}

Exam limitations are: $\bullet$ For absence of time, I could not meet the knowledge of various association duties and records.

- Most organizations are reluctant to disclose their personal data in view of their company advancement exercises just as the forthcoming Add Crusades.

- The items exceptionally advance innovation itself becomes a compelling advance in deals If the client is unable to comprehend the particular terms and conditions and their advantages. $\cdot$ Sometimes the policeman needs people who just sing their own tune to look with determination. - Unqualified drivers or clients are misusing their vehicles and misleading the association mistake or disappointment.

Forthcoming clients [29]

\section{IV.RESEARCH METHODOLOGY}

\section{RESEARCH:}

Research is an academic activity and the term should therefore be used in a particular context. As stated by Clifford Woody think tank characterizing and rethinking problem, defining theory or suggested arrangement, Sorting and evaluating data ; making reasoning and arriving at resolution ; and finally, test the ends carefully to determine if they fit the scheduling speculation.

The main motive behind studies is to discover responses to investigations using logical techniques. The basic point of the exploration is to find reality that is covered up and that has not been discovered so far.

A philosophy of examination characterizes the reason for studies, How it progresses, how progress can be measured and what the goal can be achieved chosen to do an exploration survey. Defining the appropriate study setup is nitty gritty underneath:[28]

- Exploratory research: the aim of this form of research is to improve insight into the issue. It considers the primary regions where the issue is untruthful and further attempts to assess a suitable game plan. the disturbances in Maruti Suzuki's product and

\section{V.INFORMATION COLLECTION}

- Secondary data was used that is collected through articles, reports, diaries, magazines, journals, scientists, universities, and internet reports.[29]

DATA NATURE - SECONDARY DATA: secondary information now accessible and distributed. It could be a source of information internally or externally.

- INTERNAL SOURSE: Starting from the industry or region in which the research is conducted. Browser eg-open, formal document,,,, etc.

Devices AND TECHNIQUES

- Using multiple factual instruments such as tables and graphs, information analysis was finished. - The instruments used to investigate data are the examination of rates.[30]

\begin{tabular}{|l|l|}
\hline Research used -- & Exploratory research \\
\hline kind of facts -- & Primary \& secondary data \\
\hline section devise -- & Simple random sample \\
\hline No. of sample -- & 110 \\
\hline Charts used -- & Pie, bar, line $\ldots \ldots \ldots \ldots . . . .$. \\
\hline
\end{tabular}

2. Why did you go for Maruti Suzuki? Why no other vehicle? TABLE NO-2

TITLE- Table showing respondents reason for buying Maruti Suzuki.

\begin{tabular}{|l|l|}
\hline REASONS & PERCENTAGE \% \\
\hline Style and Look & 67 \\
\hline Unique & 15 \\
\hline Comfortable & 7 \\
\hline Power staring & 2 \\
\hline Mileage & 2 \\
\hline No idea & 7 \\
\hline Total & 100 \\
\hline
\end{tabular}

\section{INTERPRETATION:}

It is evident from the above table that the largest maruti Suzuki client prefers it because of its style and look. Maruti Suzuki has more than 10 colors and it provides the rider a distinctive look, most importantly. To attract new clients, Maruti should make it vital to develop his other function.[31]

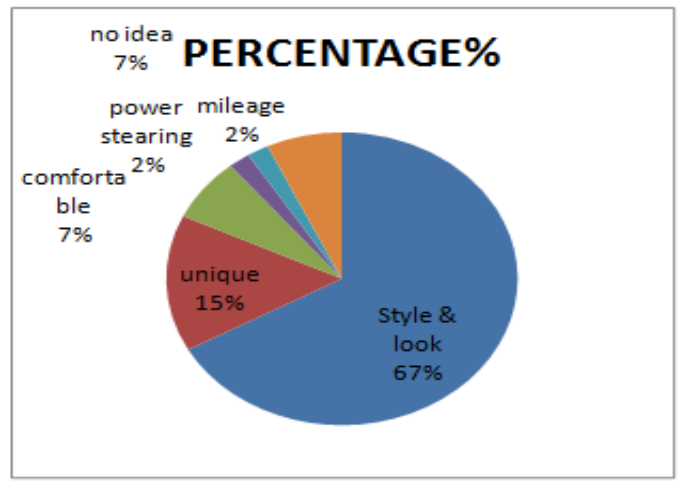

3. 3. Why felt the need for a car?

TABLE NO- 3

TITLE- Table displaying the car needs of the participants. 


\begin{tabular}{|l|l|}
\hline Need for vehicle & Percentage \% \\
\hline Emotional need & 11 \\
\hline Actual need & 89 \\
\hline Total & 100 \\
\hline
\end{tabular}

INTERPRETATION: Maruti Suzuki's purchase is a real need for maximum individuals. It's around 89 percent and some individuals have also been driven by their emotional needs.

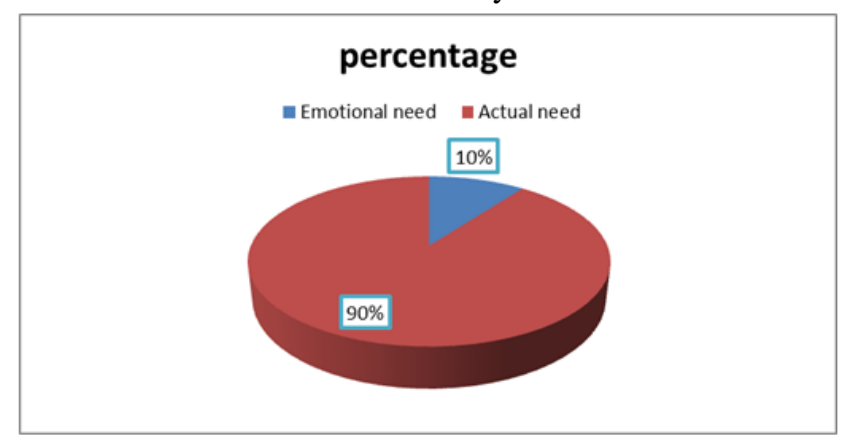

4Who is your decision-making participant?

TABLE NO- 4

Table showing respondents influencing factors.

\begin{tabular}{|l|l|}
\hline Participant in decision making & Percentage \% \\
\hline Family members & 62 \\
\hline Friends \& colleagues & 29 \\
\hline Reference group & 5 \\
\hline Society & 4 \\
\hline Total & 100 \\
\hline
\end{tabular}

\section{INTERPRETATION:}

From the above board it's obvious that $62 \%$ persons are influenced by the family members. So family members are the major factor. Similarly friends and colleagues are also influencing factors

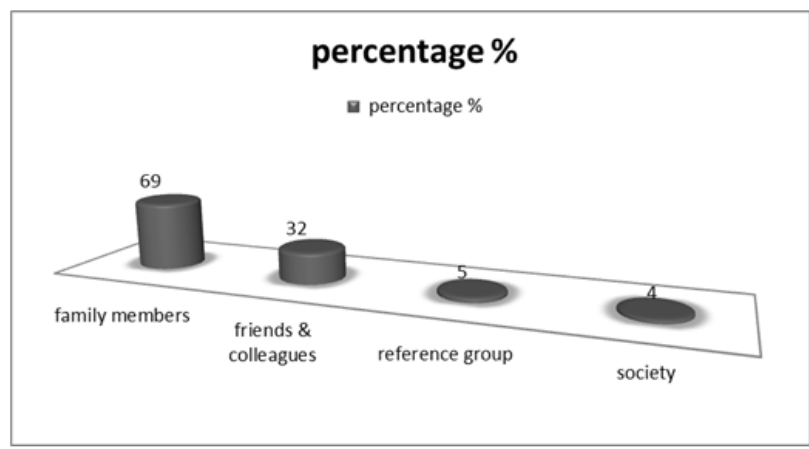

5. Did you make any compromises for purchasing Maruti Suzuki? What are they?

\section{TABLE NO- 5}

TITLE- Table showing compromises of respondents of Maruti Suzuki

\begin{tabular}{|l|l|}
\hline Compromises(reasons) & Percentage \% \\
\hline No & 71 \\
\hline Late delivery & 13 \\
\hline Heaviness & 4 \\
\hline Average & 9 \\
\hline No idea & 3 \\
\hline Total & 100 \\
\hline
\end{tabular}

\section{INTERPRETATION:}

From the research study it is apparent that generally the Maruti Suzuki customers are very much satisfied and they have no compromises after purchasing Maruti. Some people are not satisfied as they say its heavy and delivery time taken is high. So maruti should give importance to remove these problems.

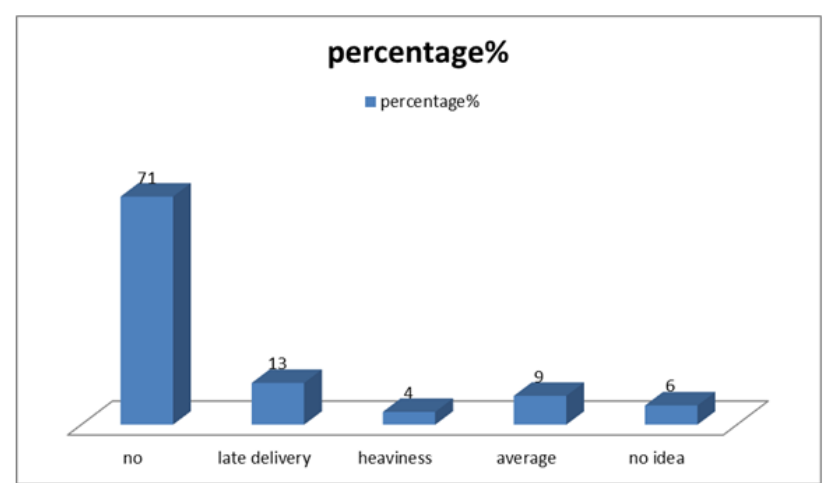

6.OCCUPATION OF THE CUSTOMER

TABLE NO- 6

TITLE- Table showing occupation of the customer.

\begin{tabular}{|l|l|l|l|}
\hline occupation & respondents & percentage & $\begin{array}{l}\text { Cumalative } \\
\text { percentage }\end{array}$ \\
\hline Student & 5 & 4.5 & 4.5 \\
\hline Business & 57 & 51.8 & 56.3 \\
\hline Employee & 26 & 23.6 & 79.9 \\
\hline Home maker & 3 & 2.7 & 82.6 \\
\hline Doctor & 19 & 17.4 & 100 \\
\hline Total & 110 & 100 & \\
\hline
\end{tabular}

\section{INTERPRETATION:}

From the table it is clear that highest number of respondents are Businessman constituting about $52 \%$ and the least percentage is students around $4.5 \%$.

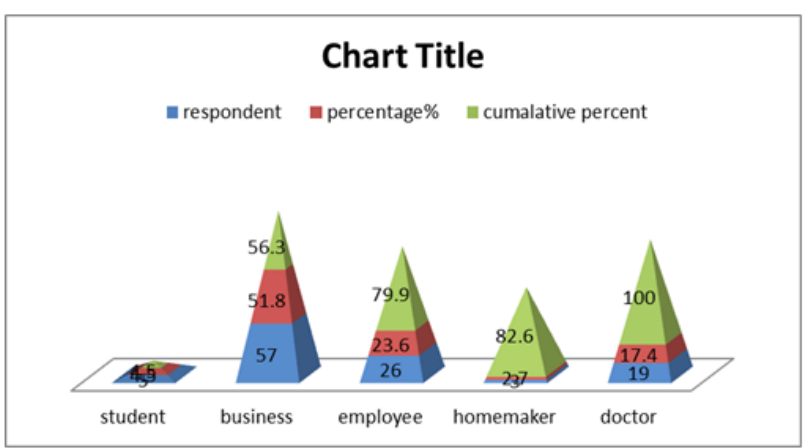

7.Respondents age group of Maruti Suzuki

$$
\text { TABLE NO-7 }
$$

TITLE- Table showing age group of the respondents

\begin{tabular}{|l|l|l|l|}
\hline $\begin{array}{l}\text { Age between } \\
\text { (years) }\end{array}$ & respondents & Percentage\% & $\begin{array}{l}\text { Cumalative } \\
\text { percentage }\end{array}$ \\
\hline $15-25$ years & 9 & 8.18 & 8.18 \\
\hline $26-35$ years & 76 & 69.09 & 77.27 \\
\hline $36-50$ years & 21 & 19.09 & 96.37 \\
\hline Above 50 & 4 & 3.63 & 100 \\
\hline
\end{tabular}

\section{INTERPRETATION:}

From the graph above, it is evident that there are as many individuals as possible having Maruti Suzuki between the age group of 26-35 years and least in above 50 years. 


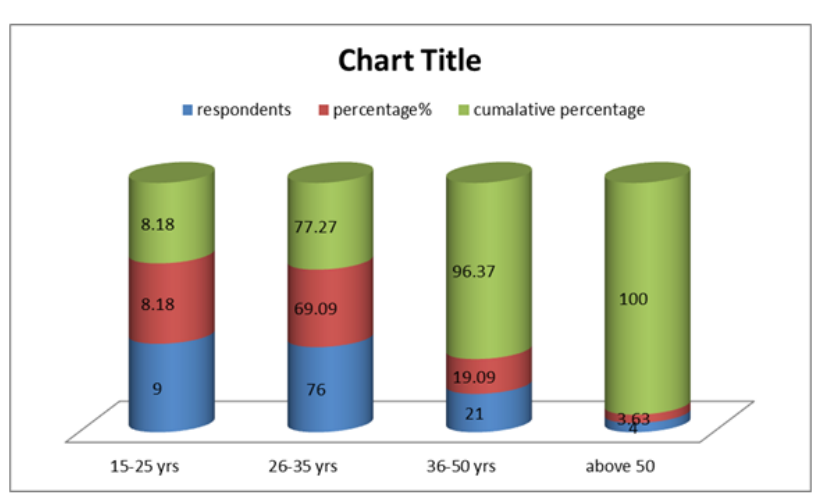

8.Annual income of the customers of Maruti Suzuki.

\section{RESULTS AND DISCUSSION}

In more youthful era, four wheeler is not extremely popular.

2. Individuals of the business class lean toward cars for their company actions (Maruti Suzuki).

3. In four wheelers, safety mode and innovation are essential.

4. Maruti Suzuki has been driven in the city for 10-12 years and is currently in No. 1 place.

5. Administration focus openness is simple.

6. Majority of clients are pleased with specialist organisation activity. [32]

7. High amount of customers are pleased with the item's decorations.

8. Most of Maruti Suzuki's clients were discovered to have $\mathrm{TV}$ as their prime media propensity, and a large part of them came from TV to think in Maruti.

9. From the market study, Maruti Suzuki's biggest client is seen

10. Unmistakably 68 percent are not fascinated from the survey to buy a comparable manufactured goods

11. The "MARUTI" brand name has a higher effect on customers ' minds. They're going to Suzuki when they see Maruti.

12. From the study, it is seen that a big part of the client's fundamental management procedure is affected by parents.

13. The participants gave their impression of making more game cars, diminishing the value, giving new and enhanced extras.

14. A big majority of respondents are leaning towards Maruti (48\%), although Mahindra is the least (7\%).

15. A bigger proportion of participants feel that Maruti is, "Somewhat better (37\%)," while the least is," somewhat more regrettable $(7 \%) "$

16. Once the vehicle parts are harmed, it comes in distinctive car shading. It arrives in dark shading and properly painted after that, which costs additional customers.

17. The majority of clients have been discovered to purchase the item based on style and look.

Recommendation
The Karlo Automobiles and Pvt showcase unit. Ltd. Maruti Udyog Ltd., too. It needed a more sensible methodology than it presented itself. In this manner, the proposition as I would see it for the organisation is as follows:

1. Company should build labor.

2. The company should keep its transfers to the customer on timetable.

3. The company should build the quantity of vehicles in its inventory. A / C for various colors and designs.

4. Company should open area shrewd investigation branch workplaces.

5. The company should cope with the worker's satisfaction.

6. Motivation ought to likewise be given to the business administrators and grumblings after deal.

7. Company should take legitimate consideration of client gratefulness and grumblings after deal.

8. The organization should give expansion blessing plans to clients other than general plans.

The above plans have been come to in the wake of contemplating and looking at the whole concerns, different utilitarian offices and based on meetings with organization execute

\section{VII.CONCLUSION}

As of late, the creation of traveler vehicles in India enrolled an enormous Development of 118 rates during the 1990s. The de-authorization of the automotive industry in 1993, however, paved the way for global automakers to Enter the nation with a plan to tap India's vast population base. Development attained an intact high record over the next 10 years In 1999, he discovered how to cross the 500,000 mark.' as it was called by some players in the car industry. It was the moment to set up duties, brands, vendors, administration system and field organizations.

The year 2001 was calibrating for fresh designs, For development, flagging the start of' organize 11 of auto India inc.' It saw a spate of new vehicle dispatches like debates, money-related inconveniences, mergers and shutdowns, both in India and around the globe. However, the market for vehicles of small size has seen a growth rate of $42 \%$, as stated by Indian car manufacturers (SIAM) society.

Today it appears that India has at long last touched base in the major group of Asian vehicle markets. Unfaltering and amazing yearly development rate , nearness of universal automakers, unwinding of remote trade and value guidelines, decrease of levies on imports and couple of other are its parts blasting auto advertise.

The nation has now come to be seen as a possibly developing business sector. The sense of outside speculators has changed, everybody requires to be here. 


\section{REFERENCES}

1. BharthVajan R., Ramachandran S.,Psychographic dimensions of training,2016,International Journal of Pharmacy and Technology,V-8,I-4,P-23727-23729

2. Balakrishnan P., Bharthvajan R.,A study on human resource planning in hospitals in Chennai City,2014,International Journal of Applied Engineering Research,V-9,I-22,P-7503-7507

3. Priyadarsini P., Bharthvajan R.,Role of emotional intelligence training programme in reducing the stress of the nurses,2014,International Journal of Applied Engineering Research,V-9,I-22,P-7411-7421

4. Kerinab Beenu G., Bharthvajan R.,Empirical analysis on the cosmetic buying behavior of young women in South India,2014,International Journal of Applied Engineering Research,V-9,I-22,P-7361-7366

5. Balakrishnan P., Bharthvajan R.,Whistling in the wind,2014,International Journal of Applied Engineering Research,V-9,I-22,P-7586-7593

6. Krishnan B., Peter M.,Health hazards of Indian Bpo employee-an alarming issue,2014,International Journal of Applied Engineering Research,V-9,I-22,P-7336-7341

7. Kerinab Beenu G.H., Peter M.,Role of insurance in economic development,2014,International Journal of Applied Engineering Research,V-9,I-22,P-7532-7539

8. 8) Balakrishnan P., Peter M., Priyadarsini P.,Efficiency of safety measures for wellbeing of employees in manufacturing industry,2014,International Journal of Applied Engineering Research,V-9,I-22,P-7376-7382

9. Anbarasi M., Praveen Kumar S.,Online sales promotions of herbal products and its effectiveness towards tanisha.com,2019,Indian Journal of Public Health Research and Development,V-10,I-1,P-195-200

10. Anbarasi M., Praveen Kumar S.,Various online marketing and promotions strategies to improve the validation towards the organic products in the pharmaceutical sectors,2019,Indian Journal of Public Health Research and Development,V-10,I-1,P-263-269

Loganathan R., Praveen Kumar S.,Grievance handling a key factor for solving issues of employees in an organization,2014,International Journal of Applied Engineering Research,V-9,I-22,P-7483-7491

11. Loganathan R., Praveen Kumar S.,Study on preference of private label brands in super and Hypermarkets,2014,International Journal of Applied Engineering Research,V-9,I-22,P-7327-7335

12. Smitha M., Praveen Kumar S.,Understanding stress and its managementamong the nurses in Chennai city,2014,International Journal of Applied Engineering Research,V-9,I-22,P-7560-7565

13. Kerinab Beenu G.H., Praveen Kumar S.,A study on the investment behavior of Chennai investors in mutual fund schemes,2014,International Journal of Applied Engineering Research,V-9,I-22,P-7520-7525

14. Loganathan R., Praveen Kumar S.,Retention strategies key for organizational productivity,2014,International Journal of Applied Engineering Research,V-9,I-22,P-7443-7447

15. Pavithra J., Ganesan M., Brindha G.,State wise analysis of microfinance sector in India,2016, International Journal of Pharmacy and Technology,V-8,I-4,P-23417-23432

16. Pavithra J., Ganesan M.,A comparative study on microfinance in India and abroad,2016,International Journal of Applied Business and Economic Research,V-14,I-8,P-5471-5476

17. Pavithra J., Ganesan M.,A study on awareness and impact of micro-financial schemes,2016,International Journal of Applied Business and Economic Research,V-14,I-8,P-5449-5460

18. Senthilmurugan P., Pavithra J.,Consumer preference towards organised retailing with reference to Big Bazaar,2014,International Journal of Applied Engineering Research,V-9,I-22,P-7469-7475

19. Senthilmurugan P., Pavithra J.,Implication of social media marketing in growing healthcare industry,2014,International Journal of Applied Engineering Research,V-9,I-22,P-7448-7456

20. 21) Loganathan R., Pavithra J.,Consumer perception towards private label brand over other brands in super markets and hypermarkets,2014,International Journal of Applied Engineering Research,V-9,I-22,P-7355-7360

21. 22) Kerinab Beenu G., Pavithra J.,Tradeâ€"off between liquidity and profitability in logistics industry,2014,International Journal of Applied Engineering Research,V-9,I-22,P-7398-7401

22. Kerinab Beenu G., Pavithra J.,A study on the prospective consumerâ $€^{\mathrm{TM}_{\mathrm{S}}}$ perception towards utility cars in Chennai city,2014,International Journal of Applied Engineering Research,V-9,I-22,P-7526-7531
23. Pavithra J., Dilli Babu P., Ambuli T.V.,A study on budgetary control at Maruti Service Masters, Chennai,2014,International Journal of Applied Business and Economic Research,V-12,I-2,P-151-161

24. Pavithra J., Dilli Babu P., Ambuli T.V.,A study on customer satisfaction of retro Garments Pvt Ltd, Chennai,2014,International Journal of Applied Business and Economic Research,V-12,I-2,P-381-391

25. Kerinab Beenu G.H., Pavithra J., Senthilmurugan P.,A study on the influence of promotional activities for TATA ARIA among consumers in Chennai,2014,International Journal of Applied Engineering Research,V-9,I-22,P-7572-7578

26. Vijayaragavan S.P.,An investigative expert that's general FBG sensors,International Journal of Mechanical Engineering and Technology,V-8,I-8,PP-1500-1505,Y-2017

27. Vijayaragavan S.P.,Equalization routing protocol for Wi-Fi sensor strategy,International Journal of Mechanical Engineering and Technology,V-8,I-8,PP-1662-1666,Y-2017

28. Karthik B., Kiran Kumar T.V.U., Vijayaragavan P., Bharath Kumaran E.,Design of a digital PLL using 0.35 $\hat{\mathrm{I}} / 4 \mathrm{~m}$ CMOS technology,Middle East Journal of Scientific Research,V-18,I-12,PP-1803-1806,Y-2013

29. Kanniga E., Selvaramarathnam K., Sundararajan M.,Kandigital bike operating system,Middle - East Journal of Scientific Research,V

30. Jasmin M., Vigneshwaran T., Beulah Hemalatha S.,Design of power aware on chip embedded memory based FSM encoding in FPGA,International Journal of Applied Engineering Research,V-10,I-2,PP-4487-4496,Y-2015

31. Jasmin M.,Optimization techniques for low power VLSI circuits,Middle - East Journal of Scientific Research,V-20,I-9,PP-1082-1087,Y-2014

32. Jasmin M., Vigneswaran T.,Fuzzy controller for error control of on Chip communication,2017 International Conference on Algorithms, Methodology, Models and Applications in Emerging Technologies, ICAMMAET 2017,V-2017-January,I-,PP-1-5,Y-2017

\section{AUTHORS PROFILE}

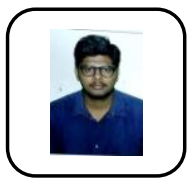

Kireethi Reddy Student, Department of Management studies,Bharath Institute of Higher Education and Research, Chennai,India.

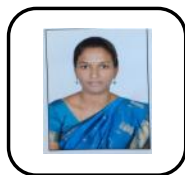

Jeyapriya Assistant Professor. Computer science and engineering Department of ,Bharath Institute of Higher Education and Research,Chennai ,India.

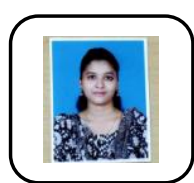

Indhumathi Student, Department of Managemen studies,Bharath Institute of Higher Education and Research, Chennai, India 